\title{
THE EFFECTIVENESS OF TENS IN REDUCING THE PAIN LEVELS AMONGST WOMEN IN THE FIRST STAGE OF GIVE BIRTH
}

\author{
Neni Nuraeni ${ }^{1}$, Ade Kurniawati ${ }^{2}$, Gugun Gundara ${ }^{3}$ \\ ${ }^{1,2,3}$ Universitas Muhammadiyah Tasikmalaya \\ Correspondence: neni.nuraeni@umtas.ac.id
}

\begin{abstract}
Abstrak
The TENS instrument is a tool as an alternative of the non-pharmacological therapies to help give birth women in dealing with pain. There are electrodes in this tool that are useful for channeling electric wave to women's back, that it stimulates the nerves in the area pain. The signal from TENS serves to disrupt the pain signals that affect the nerves and break the pain signal, as a result reducing patients' pain levels. The aim of the study was to find out the effectiveness of TENS towards decreasing pain levels in the first stage of labour. The study applied the quasi-experimental research method with the one group pre-test design approach. The population was women the first stage of labour, and samples were selected using the accidental sample technique, and five women participated in this study. Data were analysed using the dependent $\mathrm{T}$ test. The results of the study obtained TENS with a frequency of $108 \mathrm{~Hz}$ and a voltage of 82 Volt is safe to patients' skin. There was not a significant effect of TENS to the level of pain with $\rho$-value 0.374. It can be concluded that the TENS instrument that designed in this study is ineffective in managing labor pain especially the first stage. There is a need further research to test this instrument in the laboratory, and redesign it related to the instrument size and packaging.
\end{abstract}

Keywords: give birth, pain, TENS

\section{INTRODUCTION}

Labor is the process of delivering the conception result. Labor for women requires physical and psychological adaptation. The physiological responses of labor include uterine contractions from regular to strong, pain, and discomfort (Reeder, 2011; Pillateri, 2003; Bobak, 2005). Pain is a subjective experience due to ischemia of the uterine muscles, ligament traction in the reproductive organs (uteri, ovary, fallopian tube and perineum), urethral pressure, bladder and rectum, and distension of the lower abdomen and pelvic floor muscles (Reeder, 2011 ; LH HO, 2011). Uterine contractions and cervical dilatation cause pain in the 1st stage of labor. Pain is felt in the area of the lower abdomen, and the waist region, and the sacrum. The pain is visceral, blunt and unclear.

Management is needed to overcome discomfort during childbirth with the aim of having a positive response to perceived pain. Management of childbirth pain can be done pharmacologically, namely giving opoid, and non-pharmacological therapies such as acupressure, aromatherapy, back massage, hydrotherapy and relaxation such as 
Transcutaneous Electric Nerve Stimulation (TENS) (Leksana, 2011). The results of a study conducted by Karlina (2015) found TENS affected childbirth pain especially in the active stage of cervical dilatation $(8 \mathrm{~cm})$. Likewise the results of the LF HO (2011) study found that TENS can reduce pain during childbirth. Yulifah (2009) and Santana (2015) found that TENS effectively reduced childbirth pain and anxiety.

TENS is a device that is electrified with an electrode device that aims to stimulate the pain reduction nerves. This signal serves to break the pain signal so that the pain that is reduced. Another theory says that TENS can stimulate the body to produce natural painkillers, erdorphin (Djaya, 2011). Beta endorphins are released by the hyposis gland and the levels are very high during sex, pregnancy, birth and breastfeeding. This hormone can cause pleasure and euphoria during childbirth (Leksana, 2011). Therefore, researchers are interested in finding the effectiveness of TENS in reducing pain for the first stage of chilbirth.

\section{METHODS}

This research was a quantitative research study with a quasi-experimental approach: one group pretest-posttest design. The instruments used are NRS: pain scale. Data were analyzed using Paired $\mathrm{T}$ Test statistical test. Before the pain measurement, researchers designed a tool called TENS. The designed of TENS produces a frequency of $108 \mathrm{~Hz}$ and a voltage of 82 Volt. The tool was designed and tested in the Technical Laboratory of the Muhammadiyah University of Tasikmalaya. After acheiving the targeted frequency and signal, and then it tested to the respondent. Stages of data collection include: measuring respondents' pain levels using the NRS instrument, putting the electrodes on the back of patient and applying TENS for pain therapy, and again measuring the level pain after interventions. Ethical principles in this study include informed consent, confidentiality of patient identity, and guaranteeing humane right. 


\section{RESULTS}

The results of the study were divided into 2 stages: 1) the design of the TENS instrument, and 2) the application of the TENS instrument, the results as follows:

\section{Developing the TENS instrument}

This stage took for approximately 8 months. The steps for developing tools include designing and testing tools in the laboratory. This process aimed to produce a tool that have an appropriate signal and safe for patients. The expected TENS was a tool that produces a high voltage and a low current signal at a certain frequency and duration. This tool is applied externally to the body skin using sticky foam electrode pads. TENS is a machine for providing electric shocks. Measuring signals at the output of the device in this mode reveals muffled oscillations at a frequency of around $2.5 \mathrm{kHz}$, with a repetition rate of around $100 \mathrm{~Hz}$. Simple circuits use CMOS 555 timers to produce short pulses that energize a miniature transformer 1:10. Together with $4.7 \mathrm{nF}$ capacitors, the transformer makes parallel resonance circuits: resonance causes a large increase in output voltage. Adjustable pulse width using potentiometer, and combined with on-off switch. Wider pulses produce a higher output voltage. The highest voltage was up to $200 \mathrm{~V}$, the transformer must have the appropriate isolation and provide an appropriate connection to the electrode cable (See Figure 1).

\section{Picture 1. The results of the TENS design, equipped with electrodes}




The device had a frequency of $108 \mathrm{~Hz}$ and a voltage of 82 Volts. The signal at the output of the device was revealing muffled oscillations at a frequency of around $2.5 \mathrm{kHz}$, and the repetition rate is around $100 \mathrm{~Hz}$.

2. The effectiveness of TENS in reducing the pain levels in the first stage of labor

The effectiveness of TENS on the management of 1 st stage of childbirth pain can be seen in the following table:

Table 1. Analysis of women's pain levels before and after the TENS intervention

\begin{tabular}{lcccccc}
\hline & $\mathrm{N}$ & Mean & SD & SE & T & $\rho$ Value \\
\hline $\begin{array}{l}\text { Pain levels } \\
\text { Pre-post }\end{array}$ & 5 & 0,200 & 0,447 & 0,200 & $-1,000$ & 0,374 \\
TENS & & & & & & \\
\hline
\end{tabular}

Table 1 shows that the average pain before and after the TENS intervention was 0.200 , the standard deviation of 0.447 , the standard error of 0.200 with $\rho$ value 0.374 means that the TENS was not effective in decreasing childbirth pain at the 1 st stage.

\section{DISCUSSION}

The results of the study showed that the TENS was not effective in managing childbirth pain. Before intervention, the average of patients' pain levels was 8 with characteristics: pain is very sharp, hot and spreads to the back area. The respondent's expression was in pain, the face grimaced, and when the contraction disappeared, the patient calmed down and rested. In the latent phase of uterine contractions that are felt to be less painful and the patient can do some activities. This is in line with Meizack 1984 in Reeder, 2011 suggested that during the first stage of normal childbirth, discomfort or pain is caused by involuntary contractions of uterine muscles. Contractions are felt in the lower back at the beginning of labor, when labor progresses, the sensation of pain spreads to the lower body includes the abdomen and back. Contractions increase at certain intensities and then decrease, until the pain disappears. 
Contractions generally last around 45-90 seconds. The quality of pain varies and is difficult to explain, but women describe that the pain is sharp, cramped, painful like being beaten, punctured, hot like being shot, heavy tiring, and tight.

After TENS intervention that aimed to help patients to be able to manage their pain, the average women's pain remained or increased by approximately in levels 8-9. This is possible may because of the electric shocks are too strong to cause a shock, and TENS must be applied continuously, the effect may not maximum if the signal produced is only once. The results of this study are not in line with Karlinah (2015) suggested that TENS effectively reduces the intensity of childbirth pain when cervical dilated about $8 \mathrm{~cm}$ compared to acupressure will be effective at $4 \mathrm{~cm}$ of the cervical dilatation. LF HO (2011) suggested that TENS effectively reduced childbirth pain intensity by $38 \%$ of respondents. This might be due to the difference of tools. In this study researchers used a TENS that produced by the research team.

The TENS we designed produces a frequency of $108 \mathrm{~Hz}$ and a voltage of 82 Volts. The signal at the output of the device in this mode reveals muffled oscillations at a frequency of around $2.5 \mathrm{kHz}$, with a repetition rate of around $100 \mathrm{~Hz}$. This is in line with the theory presented by Djaya (2011) and Watson (2013) that TENS is carried out by direct contact of the device with the patient through the electrode, so that the device is designed to meet safety standards so that no burns occur on the skin, with $50 \mathrm{~mA}$ with a frequency of $10-250 \mathrm{~Hz}$ which is widely used for reducing pain. The fundamental theory of TENS 'working principle is the theory of pain gates proposed by Melzack and Wall. According to this theory TENS is thought to activate specifically peripheral A beta in the dorsal horn region so that it modulates A delta and $\mathrm{C}$ fibers that deliver pain. 


\section{CONCLUSION}

It can be concluded that the designed TENS produces a frequency of $108 \mathrm{~Hz}$ and a voltage of 82 Volt is safe for direct skin contact with patients. The signal at the device output in this mode reveals muffled oscillations at a frequency of around $2.5 \mathrm{kHz}$, with a repetition rate of around $100 \mathrm{~Hz}, \mathrm{PV}$ values 0.374 . TENS developed to reduce pain in the1st stage childbirth had $\rho$-value of 0.374 . It is recommended that further research on the pain relief devices would be useful to help women in controlling pain at the 1st stage of labor. Further research is needed to re-examine laboratory use of TENS, and redesign so the size of the tool is smaller and packaged more simply.

\section{ACKNOWLEDGEMENT}

1. The Ministry of research and higher education of Republic Indonesia that have given grants in this study

2. Chancellor of the Muhammadiyah University of Tasikmalaya

3. Dean of the Faculty of Health Sciences, University of Muhammadiyah Tasikmalaya

4. Dean of Faculty of Technich Universitas Muhammadiyah Tasikmalaya

5. Chairperson of the Institute for Research and Service to the Community of Muhammadiyah Tasikmalaya

6. Chair of Nursing D III Study Program, Faculty of Health Sciences, University of Muhammadiyah Tasikmalaya

7. Chair of the Midwifery Diploma III Study Program at the Faculty of Health, University of Muhammadiyah Tasikmalaya

8. Chair of the Mechanical Engineering Study Program at the Faculty of Engineering, University of Muhammadiyah Tasikmalaya 
9. Head of Technical Implementation Unit of the Technical Laboratory of the University of Muhammadiyah Tasikmalaya

10. Colleagues and colleagues who have supported us to conduct this research

\section{REFERENCES}

American Medical Association. (2007). Module 1 pain management: Pathofisiology of pain and pain assessment. Retrieved from web September 15, 2008. http://www.amacmeonline.com/pain_mgmt/module01/index.htm

American Medical Association. (2007). Module 10 pain management: Pathofisiology of pain and pain assessment. Retrieved from web September 15, 2008. http://www.amacmeonline.com/pain_mgmt/module10/index.htmPerry \& Potter. 1997. Fundamentals of nursing: Concepts, process and practice. Mosby Company:

$\underline{B e d w e l l ~ C}^{1}$, Dowswell T, Neilson JP, Lavender T.(2011). The use of transcutaneous electrical nerve stimulation (TENS) for pain relief in labour: a review of the evidence.Midwifery. 2011 Oct;27(5):e141-8. doi: 10.1016/j.midw.2009.12.004. Epub 2010 Feb 18.

Bobak. (2005). Keperawatan maternitas. Edisi 4. Jakarta: EGC.

Djaya. (2011). Elektronika Biomedik; TRanscutaneous Electrical Nerve Stimulation. https://ejournal.unsrat.ac.id/index.php/biomedik/article/download/6325/5845

Evan, (2010) Evan, R. M. (2010) Pathophysiology of Pain and Pain Assessment. American Medical Association. 1-12.

Hutagaol. (2007). Perbedaan pengaruh Intervensi MWD dan TENS dengan MWD, TENS dan Traksi Leher Manual terhadap Pengurangan Nyeri Kepala pada Cervical Headche. http://digilib.esaunggul.ac.id/public/UEU-Journal-3982-Hutagalung.pdf 
Jiemesha. (2014). Pengaruh Trnscutaneous Electrical Nerve Stimulation dengan dan tanpa terapi latihan terhadap nyeri dan kinerja fisik pada penderita osteoarthritis lutut. Jurnal Biomedik (JBM), Volume 6, Nomor 3, November 2014. https://ejournal.unsrat.ac.id/index.php/biomedik/article/download/6325/5845 Karlinah. (2015). Pengaruh Tehnik Akupresur dan TENS terhadap Intensitas Nyeri Persalinan Kala 1 fase Aktif.Jurnal Kesehartan Andalas. 2015;4 (3). http://jurnal.fk.unand.ac.id/index.php/jka/article/viewFile/395/349

Leksana, Ery. (2011). Mengatasi Nyeri Persalinan. CDK 185. Vol. 38 No 4. Juni-Juli 2011. www.kalbemed.com/Portals/6/25_1850pinipendekatanfarmakologis.pdf

LF Ho, Ly Lee and Gy Ma. (2011). Intrapartum Trnscutaneous Electrical Nerve Stimulation for pain relief and outcome of labor.Hong kong Journal of Gynaecology Obstretic and Midwifery 11(1) . http://www.hkjgom.org/sites/default/files/pdf/v11-p54intrapartum.pdf

Muttaqin, A.(2011). Asuhan Keperawatan Klien dengan Gangguan Sistem Kardiovaskular dan Hematologi. Jakarta : Salemba Medika.

Nuach. (2014). Pemberian Trnascutaneous Electrical Nerve Stimulation (TENS) menurunkan intensitas nyeri pada pasien bedah urologi di ruang rawat inap marwah RSU Haji Surabaya. Jurnal FK Unair. http://journal.unair.ac.id/download-fullpaperscmsnj33b48bc1c42full.pdf

Perry \& Potter. (2005).Fundamental keperawatan;konsep,proses dan praktik. Vol 1. Edisi 4. Jakarta: EGC.

Pillitteri, A. (2003). Maternal \& child nursing. $2^{\text {nd }}$ ed. Philadelphia : J. B Lippincott 
Reeder, Martin \& Griffin. (2011). Keperawatan maternitas;kesehatan wanita, bayi dan keluarga. Alih bahasa; Afiyanti, Nur Rachmawati dkk (2003/2011). Edisi 18. Volume 1. Jakarta: EGC.

Santana.(2015). Transcutaneous Electrical Nerve Stimulation (TENS) reduce pain and postpones the need for pharmacological analgesia during labour: a randomized trial. Journal of Physiotherapy.http://www.journalofphysiotherapy.com/article/S1836$\underline{9553(15) 00128-9 / \mathrm{pdf}}$

Watson. (2013). Transcutaneous Electrical Nerve Stimulation. www.electrotherapy.org/assets/.../TENS\%20Jan\%202016.pdf

Yulifah, Rita; et all. (2009). Penggunaan Stimulli Trnascutaneous Electrical Nerve Stimulation (Tens) dapat menurunkan Intensitas Nyeri dan Tingkat Kecemasan pada Persalinan Kala 1. The Indonesian Journal of Public Health, Vol 5 NO 3, Maret 2009 : 119-123. 3899-ID-penggunaan-stimuli-transcutaneous-electrical-nerve-stimulation-tensdapat-menurun 